\title{
Validation and reliability of the scale Self-efficacy and their child's level of asthma control
}

\author{
Validação e confiabilidade da Self-efficacy and their child's level of asthma control \\ Validación y confiabilidad de la Self-efficacy and their child's level of asthma control
}

\section{Ana Lúcia Araújo Gomes', Emanuella Silva Joventino", Kamila Ferreira Lima', Regina Cláudia Melo Dodt"', Paulo César de Almeida 'v', Lorena Barbosa Ximenes' \\ ' Universidade Federal do Ceará, Postgraduate Program in Nursing. Fortaleza, Ceará, Brazil. \\ "Universidade da Integração Internacional da Lusofonia Afro-Brasileira, Institute of Health Sciences. Redenção, Ceará, Brazil. \\ I"' Universidade Federal do Ceará, Pharmacy, Odontology and Nursing School. Fortaleza, Ceará, Brazil. \\ Iv Universidade Estadual do Ceará, Postgraduate Program in Clinical Care in Nursing and Health. Fortaleza, Ceará, Brazil.}

\section{How to cite this article:}

Gomes ALA, Joventino ES, Lima KF, Dodt RCM, Almeida PC, Ximenes LB. Validation and reliability of the scale Self-efficacy and their child's level of asthma control. Rev Bras Enferm [Internet]. 2018;71(2):406-12.

DOI: http://dx.doi.org/10.1590/0034-7167-2016-0528

Submission: 11-11-2016 Approval: 03-19-2017

\section{RESUMO}

Objetivo: Avaliar as propriedades psicométricas em termos de validade e confiabilidade da escala Self-efficacy and their child's level of asthma control: versão brasileira. Método: Estudo metodológico em que participaram 216 pais/cuidadores de crianças com asma. Procederam-se a validação de construto (análise fatorial e testagem de hipóteses por comparação de grupos contrastados), confiabilidade em termos de homogeneidade (alfa de Cronbach) e estabilidade (teste-reteste). Resultados: A análise fatorial exploratória mostrou-se adequada para a versão brasileira da escala (Kaiser- Meyer-Olkim de 0,879 e a esfericidade de Bartlett com $p<0,001$ ). A matriz de correlação na análise fatorial sugeriu a retirada do item 07 , sendo o Alfa de Cronbach final da escala com 16 itens de 0,92. Conclusão: A versão brasileira da Self-efficacy and their child's level of asthma control apresentou propriedades psicométricas que comprovam sua validade e confiabilidade.

Descritores: Asma; Criança; Autoeficácia; Promoção da Saúde; Psicometria.

\begin{abstract}
Objective: To evaluate the psychometric properties in terms of validity and reliability of the scale Self-efficacy and their child's level of asthma control: Brazilian version. Method: Methodological study in which 216 parents/guardians of children with asthma participated. A construct validation (factor analysis and test of hypothesis by comparison of contrasted groups) and an analysis of reliability in terms of homogeneity (Cronbach's alpha) and stability (test-retest) were carried out. Results: Exploratory factor analysis proved suitable for the Brazilian version of the scale (Kaiser-Meyer-Olkim index of 0.879 and Bartlett's sphericity with $\mathrm{p}<0.001)$. The correlation matrix in factor analysis suggested the removal of item 7 from the scale. Cronbach's alpha of the final scale, with 16 items, was 0.92. Conclusion: The Brazilian version of Self-efficacy and their child's level of asthma control presented psychometric properties that confirmed its validity and reliability.
\end{abstract}

Descriptors: Asthma; Child; Self-Efficacy; Health Promotion; Psychometry.

\section{RESUMEN}

Objetivo: Evaluar las propiedades psicométricas en términos de validez y confiabilidad de la escala Self-efficacy and their child's level of asthma control: versión brasileña. Método: Estudio metodológico del cual participaron 216 padres/cuidadores de niños con asma. Se procedió a la validación del constructo (análisis factorial y testeo de hipótesis por comparación de grupos contrastados), confiabilidad en términos de homogeneidad (alfa de Cronbach) y estabilidad (test-retest). Resultados: El análisis factorial exploratorio se mostró adecuado para la versión brasileña de la escala (Kaiser-Meyer-Olkim de 0,879 y esfericidad de Bartlett con $\mathrm{p}<0,001)$. La matriz de correlación en el análisis factorial sugirió el retiro del ítem 07, resultando el Alfa de 
Cronbach final de la escala con 16 ítems de 0,92. Conclusión: La versión brasileña de la Self-efficacy and their child's level of asthma control expresó propiedades psicométricas que comprueban su validez y confiabilidad.

Descriptores: Asma; Niño; Autoeficacia; Promoción de la Salud; Psicometría.

\section{INTRODUCTION}

Asthma is a chronic disease that presents high mortality indicators in developing countries, especially in low-income populations, to which risk factor reduction strategies and adequate control of the illness are still incipient ${ }^{(1)}$.

Childhood asthma is considered complex, multifactorial and distinctly severe. It demands a systemic and integrated care approach, with a focus on pharmacological and nonpharmacological aspects ${ }^{(2-3)}$ and special attention to health education and support from healthcare teams and guardians ${ }^{(4)}$.

Asthma control also depends on behavioral factors, and selfefficacy is an important predictor of therapeutic ${ }^{(5)}$ adherence and an additional tool to control the disease ${ }^{(6)}$. The concept of selfefficacy has been incorporated into the nursing context as an essential component of health promotion ${ }^{(7)}$. When associated with the development of skills and competencies, self-efficacy helps tackle asthma management complexities, impacting the quality of life of affected people and morbidity indicators positively ${ }^{(8)}$.

To know the relationship between the perceived self-efficacy of parents/guardians and childhood asthma control, Wood et al. ${ }^{(5)}$ developed a scale entitled Self-efficacy and their child's level of asthma control. The tool was underpinned by clinical guidelines and Bandura's self-efficacy theoretical framework ${ }^{(9)}$ and consists of 17 items and two domains - expected efficacy and expected results -, providing an assessment of the confidence of parents/ guardians in an efficient management of childhood asthma and in the way this care generates results in control parameters.

The Self-efficacy and their child's level of asthma control scale has been translated and adapted to Portuguese according to Beaton's steps ${ }^{(10)}$ : translation into a language by two independent translators, summary of the resulting material, translation of this synthesis back to the original language, and pretest - a pilot study of the translated version with 30 parents/guardians. But the application of the scale requires an evaluation of its psychometric properties. Hence, the objective of the present study was to assess the psychometric characteristics of the Self-efficacy and their child's level of asthma control: Brazilian version by testing its validity and reliability.

\section{METHOD}

\section{Ethical aspects}

The investigation proposal was examined and approved by the Research Ethics Committee of the Federal University of Ceará to meet the recommendations of Resolution 466/12 of the National Health Council, regarding human research. Data collection started after the signature of a free and informed consent form by parents/guardians that deal with children with asthma, who kept a copy of the document.

\section{Study design, place and period}

The present study was methodological and oriented to validate the psychometric properties of the Brazilian version of the Self-efficacy and their child's level of asthma control scale. People were recruited in the Pediatric Asthma Care Program in three primary healthcare units located in one of the most populous neighborhoods in Fortaleza, state of Ceará, Brazil, from April to July 2014.

\section{Population or sample: inclusion and exclusion criteria}

The sample consisted of 216 parents/guardians of children with asthma. Inclusion criteria were being parents/guardians of children from two to twelve years old, having the child assisted in the Pediatric Asthma Care Program, being enrolled at the referred primary healthcare units, and having a diagnosis of asthma and a prescription of inhalational treatment. Exclusion criteria were parents/guardians that presented understanding issues or physical disabilities, e.g. deafness, that prevented the correct filling of the scale, an associated diagnosis of other lung pathologies that made asthma hard to control, avoiding improvements in clinical symptoms, even after adherence to drug treatments and other forms of therapy.

\section{Study protocol}

The Self-efficacy and their child's level of asthma control: Brazilian version was translated and adapted in the initial phases of a translation and transcultural adaptation study ${ }^{(11)}$, in a scale with 17 Likert-type items, each one with a score from 1 to 5 , in which 1 means "I completely disagree", 2 stands for "I do not agree", 3 corresponds to "I am not sure", 4 indicates "I agree" and 5 expresses "I completely agree", with a total score varying from 17 to 85 points. The tool has two domains: expected efficacy and expected results.

Data collection occurred in two steps. In the first, an interview was conducted with 216 parents/guardians in a home visit, during which the scale was applied, together with an instrument designed by the authors to identify the sociodemographic profile of the sample and control parameters of childhood asthma. It is important to stress that the higher the score in the scale, the higher the confidence of parents/guardians as regards their children's asthma control. The second phase can be regarded as a pilot study and consisted of a new application of the scale with 30 parents/guardians one month after the first visit through phone calls. The goal was to assess the predictive validity and the reliability of the tool through a test-retest procedure.

The construct validity was examined through factor analysis and tests of hypothesis by comparison of contrasted groups. Reliability was assessed in terms of homogeneity, from the calculation of Cronbach's alpha, and stability was confirmed through test-retest.

To validate the scale by comparison of contrasted groups, it was necessary to standardize the instrument. This procedure 
was performed after factor analysis, taking into account that such evaluation was fundamental to determine the number of items in the final Brazilian version.

The two hypotheses tested through the contrasted groups' approach were: 1) parents/guardians with less than nine years of formal education obtain a lower score for self-efficacy in the control of childhood asthma and 2) higher self-efficacy scores are related to better childhood asthma control parameters.

\section{Analysis of the results and statistical processing}

Factor analysis was carried out through the factor matrix or component matrix (correlation matrix), the Kaiser-MeyerOlkim criterion, a scree plot and Bartlett's test of sphericity. It is recommended that the scale keeps only items with coefficients equal to or higher than $0.3^{(12)}$.

Calculations were performed by the Statistical Package for the Social Sciences (SPSS) software, version 20, license 10101131007. Exploratory data analysis consisted of a chisquare test, with $\mathrm{p}<0.05$ indicating significance.

The homogeneity of the scale can be examined through Cronbach's alpha, which varies from 0 to 1 or 0 to $100 \%$. Values higher than $70 \%{ }^{(5)}$ assure reliability ${ }^{(13)}$. The intraclass correlation coefficient (ICCC) must be calculated when the instrument provides discrete or continuous values, which is the case of total scores ${ }^{(14)}$. In the test-retest, the correlation between the outcomes from both instruments was evaluated through the calculation of Spearman's correlation coefficient ${ }^{(15)}$.

\section{RESULTS}

Most parents/guardians were between 30 to 49 years old $(\mathrm{N}=119 ; 56 \%)$, with an average age of 39 years $( \pm 11.96)$, had less than nine years of education ( $N=162 ; 82 \%)$, lived with a partner in a regular marriage or consensual union $(\mathrm{N}=$ $152 ; 72 \%$ ) and dedicated exclusively to household chores ( $N$ $=147 ; 69 \%)$. Most families presented only one member with a paid activity ( $\mathrm{N}=157 ; 73 \%$ ), did not have complementary income from social security programs $(\mathrm{N}=194 ; 91 \%)$, lived with less than $\mathrm{R} \$ 1,083(\mathrm{~N}=145 ; 77 \%)$ and were beneficiaries of the Bolsa Família program ( $\mathrm{N}=124 ; 57 \%)$. Most children with asthma were females (54\%) and belonged to the age group of 2 to 10 years old (71\%).

A factor analysis of the translated scale was run to confirm the domains of the original instrument. To achieve this, it was necessary to reach a minimum number of five people for each item in the scale, as literature advocates ${ }^{(12)}$. The ratio of participants per item was 12.76 and consequently the tool could be submitted to this type of statistical analysis. The calculated Kaiser-Meyer-Olkin index was 0.879 and Bartlett's sphericity test was considered statistically significant ( $p<0.001)$.

As for the principal component analysis, two components with eigenvalues higher than 1.50 were found and two domains were obtained (9.468, eigenvalues; 2.170 , applied variance), taking into account that this cutoff justified $68.45 \%$ of the total data variance. The scree plot (Figure 1) helped confirm this outcome and suggested that only the two first factors should be considered.

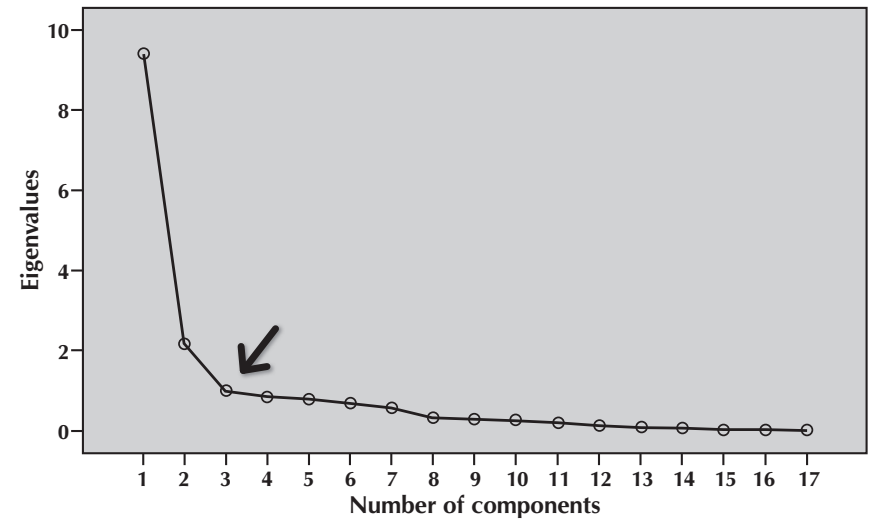

Figure 1 - Scree plot showing the eigenvalues as a function of the number of components of the scale

The component matrix was obtained through a varimax rotation with two solution factors to replicate the original study. Thus the items that constituted each factor presented consistency; factor 1 was coherent with the expected efficacy domain (items 1 to 8 ) and factor 2 represented the expected results domain (items 9 to 17). Nevertheless, factor 8 was allocated to factor 1 , contrarily to its insertion in the original scale. The item remained in factor 2 to meet the conceptual framework.

It is worth emphasizing that item 7, "I feel confident that I can help my child use a peak flow meter correctly", presented a factor loading lower than 0.3 , which indicates that it should be removed from the scale (Table 1). However, the authors opted to evaluate the other psychometric properties to confirm the exclusion of this item.

It was found that $47.7 \%$ of the parents/guardians obtained scores of 67 points; this value was chosen as the cutoff to determine the levels of self-efficacy. The lowest score was 58 points, that is, 41 points higher than the minimum score of 17 points. A percentile calculation established that total scores from 58 to 67 characterize moderate self-efficacy and total scores from 68 to 85 indicate high self-efficacy.

In the comparison by contrasted groups, the first hypothesis of the study was confirmed, considering that the higher the number of education years of parents/guardians, the higher the self-efficacy scores in the scale ( $p=0.001)$.

The second hypothesis was also validated: the higher the self-efficacy scores, the better the outcomes regarding the following childhood asthma control parameters: non-scheduled medical appointments ( $p=0.001$ ), visits to emergency units $(\mathrm{p}=0.001)$, hospital admissions in the past 12 months ( $p=$ $0.005)$, limitations in physical activities ( $p=0.003)$, missed school days ( $p<0.001)$, and sleep impairment $(p<0.001)$.

Cronbach's alpha for the complete scale, with the 17 original items, was 0.87 , which revealed a high internal consistency of the instrument, evidenced by the ICCC, with an average value of $0.871(p=0.001 ; \mathrm{Cl}=95 \%)$. Removal of item 7 , indicated by the correlation matrix in factor analysis, resulted in a new value for Cronbach's alpha (0.92), showing that the instrument kept its reliability without the specified item (Table 2). 
Table 1 - Correlation matrix between items and domains of the Self-efficacy and their child's of level asthma: Brazilian version scale, Fortaleza, Ceará, Brazil, 2015

\begin{tabular}{lcc}
\hline & \multicolumn{2}{c}{ Components } \\
\cline { 2 - 3 } Items & $\begin{array}{c}\text { Factor 1 } \\
\text { Expected efficacy }\end{array}$ & $\begin{array}{c}\text { Factor 2 } \\
\text { Expected results }\end{array}$ \\
\hline 1 & .541 & \\
2 & .605 & \\
3 & .689 & \\
4 & .735 & \\
5 & .672 & \\
6 & .539 & \\
7 & .114 & \\
8 & .627 & .651 \\
9 & & .659 \\
10 & & .664 \\
11 & & .620 \\
12 & & .426 \\
13 & & .654 \\
14 & & .640 \\
15 & & .647 \\
16 & & .629 \\
17 & & \\
\hline
\end{tabular}

Note: Extraction method: principal component analysis; rotation method: varimax.

Table 2 - List of the scale items showing the total Cronbach's alpha and the Cronbach's alpha obtained after removal of an item, Fortaleza, Ceará, Brazil, 2015

\begin{tabular}{ccc} 
Items & Item-total correlation & Cronbach's alpha if an item is removed \\
\hline 1 & .521 & .863 \\
2 & .668 & .858 \\
3 & .748 & .855 \\
4 & .776 & .852 \\
5 & .547 & .862 \\
6 & .275 & .880 \\
7 & -.344 & .927 \\
8 & .654 & .858 \\
9 & .830 & .854 \\
10 & .815 & .855 \\
11 & .789 & .855 \\
12 & .759 & .856 \\
13 & .302 & .872 \\
14 & .735 & .856 \\
15 & .760 & .856 \\
16 & .752 & .856 \\
17 & .767 & .856 \\
\hline
\end{tabular}

Test-retest stability was calculated by obtaining the Spearman-Brown (0.80) and Pearson ( $r=0.65 ; p=0.001)$ coefficients and revealed that the correlation between the results of the two applications is strongly positive. Test-retest also showed that the instrument was well accepted and was easily and quickly applied - eight minutes on average.
The final version of the scale had two factors, expected efficacy and expected results, like the original instrument. The first factor encompassed six items (from 1 to 6 ) and the second factor contained ten items (from 7 to 16), with a total of 16 items and a score varying from 16 to 80 points (Chart 1 ).

Chart 1 - Final version of the scale Self-efficacy and their child's level of asthma control: Brazilian version, Fortaleza, Ceará, Brazil, 2015

Final version of the scale Self-efficacy and their child's level of asthma control: Brazilian version

1. Eu me sinto confiante de que posso reconhecer os fatores que provocam asma na criança (I feel confident that I can recognize my child's asthma triggers)

2. Eu me sinto confiante de que vou saber reconhecer quando a criança precisa usar medicação (I feel confident that I will know when my child needs his/her medications)

3. Eu me sinto confiante de que eu sei cuidar da asma em casa e sei quando devo ir ao serviço de saúde (I feel confident that I know when to manage my child's asthma myself and when I should go to the physician)

4. Eu me sinto confiante que eu entendo as orientações dos profissionais de saúde em relação ao tratamento da asma da criança (I feel confident that I understand the directions from the physician regarding the treatment of my child's asthma)

5. Eu me sinto confiante de que posso ajudar a criança a usar o inalador corretamente (Exemplo: usar a bombinha) (I feel confident that I can help my child use an inhaler correctly)

6. Eu me sinto confiante de que posso ajudar a criança a usar o espaçador corretamente (I feel confident that I can help my child use an spacer correctly)

7. Eu acredito que cuidar da asma da criança vai resultar em menos consultas médicas (I believe that managing my child's asthma will result in less physician visits)

8. Eu acredito que cuidar da asma da criança vai resultar em menos visitas aos serviços de emergência (I believe that managing my child's asthma will result in less emergency department visits)

9. Eu acredito que cuidar da asma da criança irá resultar em menos internamentos (I believe that managing my child's asthma will result in less hospital stays)

10. Eu acredito que cuidar da asma da criança poderá me custar menos dinheiro no futuro (I believe that managing my child's asthma may cost me less money later)

11. Eu acredito que cuidar da asma da criança resultará em menos dias de faltas na escola (I believe that managing my child's asthma will result in less school day missed)

12. Eu acredito que cuidar da asma do meu filho resultará em melhores notas escolares para ele (I believe that managing my child's asthma will result in my child getting better grades)

13. Se a asma da criança é controlada, ela será capaz de participar das atividades escolares (If your child's asthma is controlled, your child will be able to participate in school activities)

14. Se a asma da criança é controlada, ela se sentirá melhor (If your child's asthma is controlled, your child will feel better)

15. Se a asma da criança é controlada, ela dormirá melhor (If your child's asthma is controlled, your child will sleep better)

16. Se a asma da criança é controlada, ela terá uma melhor qualidade de vida (If your child's asthma is controlled, your child will have a better quality of life) 


\section{DISCUSSION}

Validation through factor analysis confirmed the existence of two domains in the Brazilian version of the scale through the scree plot, which displays all the components that must be kept with eigenvalues present in the downward curve that are above (or before) the first curve, because these factors justify most data variance ${ }^{(16)}$.

Factor analysis suggested the removal of item 7, "I feel confident that I can help my child use a peak flow meter correctly". The authors believe that this result can be explained by the fact that the Brazilian public health system did not provide peak expiratory flow meters until the end of the data collection of the present study. Hence, the scale has to be adapted to the reality of the country.

In addition, item 8, "I believe that managing my child's asthma will result in fewer physician visits", did not fit into factor 1 (expected efficacy) according to a theoretical and conceptual analysis and was inserted in factor 2 (expected results). This conduct has been observed in other studies in the instrument validation field ${ }^{(17-18)}$.

A correlation was observed between the self-efficacy levels of parents/guardians and their degree of education ( $p=$ 0.001), attesting the first hypothesis of contrasted groups, which stated that people with more than nine years of formal education present higher self-efficacy scores. The Child Development Index comprehends, among other variables, care and protection that families must provide the children in the first years of life, and parents/guardians' level of education is one of the determining indicators to assess this factor ${ }^{(19)}$.

Taking into account asthma's chronicity, its management is centered in families, and it is fundamental that parents/guardians have the necessary information to assist their children effectively. A study carried out in New Zealand detected that guardians with a low education level have difficulty to understand printed educational materials and prophylaxis measures and to use inhalation devices, facts that interfere with asthma control parameters ${ }^{(20)}$.

According to an investigation carried out in the United States to obtain the clinical validation of the original scale, low level of education of parents was correlated with a lower self-efficacy, although it was not considered a predictor of inadequate asthma control parameters ${ }^{(5)}$. This finding differs from the one reported in a randomized controlled clinical trial conducted in Iran. In this case, the parents' level of education influenced the acquisition of knowledge, which may have influenced the care delivered to their children ${ }^{(21)}$. Other studies $^{(22-23)}$ corroborate that few years of education is a risk factor for the worsening of childhood asthma.

In the face of the results of the present study, it is worth stressing that the second hypothesis was also confirmed: the higher the self-efficacy scores obtained by parents/guardians in the scale, the better the results in childhood asthma control parameters.

In many cases, asthma control is not achieved because of the gap between the recommended and the executed care. An investigation developed in China, with the application of the questionnaire Knowledge, Attitude and Practice with 2,960 parents/guardians, concluded that low scores in questions related to knowledge, attitudes, and practices reflect on childhood asthma control parameters ${ }^{(24)}$.

Another study from Latin America with 2,169 patients aged 12 years old or older with asthma revealed that $60 \%$ of the interviewed people declared that their disease was controlled or well controlled, but only $8 \%$ fulfilled the Global Initiative for Asthma criteria for well-controlled asthma ${ }^{(25)}$.

Non-controlled asthma results in visits to emergency units and hospital admissions ${ }^{(26)}$. Despite the guidelines for asthma management, advances in pharmacological treatments and strong evidence of the effects of control medication on the attacks, the number of visits and admissions remains high ${ }^{(27)}$. This was not observed in the present study, given that higher self-efficacy scores in the scale were associated with better control parameters, as mentioned previously.

Hospital admissions, as a non-controlled asthma parameter, cannot go unnoticed by healthcare professionals. They must be an opportunity to review the efficacy of asthma home management and determine the strategies to improve the control of the disease ${ }^{(4)}$.

A study developed in the United States showed that the low-income population affected by asthma faces significant challenges to manage the costs of non-scheduled visits to emergency units. These issues can make families postpone or even give up their search for medical assistance, leading to an attempt to handle the situation at home, which may contribute to a poor prognosis in the treatment of asthma attacks ${ }^{(27)}$.

A study conducted in South Carolina, United States, with 19,512 people, reported that suppression or non-use of control medication is a strong risk predictor for worsening of symptoms and hospital admissions ${ }^{(28)}$. In accordance with this research, another investigation revealed that the use of control medication is essential for the remission of exacerbated asthma, reduces the number of admissions and readmissions in emergency services, and can bring benefits in the short run ${ }^{(29)}$.

Asthma control poses specific challenges and can be influenced, to some extent, by self-efficacy. Reinforcing it in parents, guardians, and patients has the potential to improve the capacity of self-management of chronic illnesses, especially childhood asthma ${ }^{(17)}$. A study carried out in Florida, United States $^{(30)}$, concluded that parents with a high perceived selfefficacy also showed better results in control parameters of the disease, corroborating the findings of the present study.

To intervene in parents' and guardians' self-efficacy appropriately, it is necessary to use validated and reliable instruments to help clinical practice. Self-efficacy and their child's level of asthma control: Brazilian version proved to be a valid scale, with Cronbach's alpha values close to 1 and higher than the one achieved by the original instrument, $0.82^{(5)}$. It is worth stressing that values between 0.7 and 0.8 are considered acceptable $^{(5)}$. In addition, the test-retest allowed to predict that behaviors of people with different levels of self-efficacy can be changed throughout different time periods ${ }^{(14)}$.

\section{Study limitations}

The main limitation that has to be taken into account to extrapolate the findings of the present study is sample losses 
( $n=63$ ), related to the characteristics of the investigated community, in which address changes, urban violence and difficult access to the dune area are common issues. Despite this limitation, it is worth emphasizing that the original sample size was appropriate for evaluation of the psychometric properties of the scale, as the literature of the field advocates.

\section{Contributions to the fields of nursing, health, or public policy}

Healthcare professionals, especially nurses that work in primary healthcare units and follow-up outpatient care programs oriented to people with asthma, should give more consistency to the evaluation of childhood asthma when using Self-efficacy and their child's level of asthma control periodically. Their efforts would facilitate the orientation of educational interventions to the items with the lowest scores, given that reduced levels of self-efficacy of parents/guardians can impair the control of the condition.

The costs to the health system originated by the consequences of asthma justify the use of a tool that can be easily and quickly applied, such as the scale examined in the present study, to help assist children with asthma, mainly the ones whose disease is difficult to control. In addition, the implementation of the instrument can improve the reorganization of the services to prioritize assistance to parents/guardians with low levels of perceived self-efficacy, including periodic reviews in this parameter, and the management of competencies and skills for asthma control.

\section{CONCLUSION}

The present study met the proposed goal regarding the analysis of reliability and validation of the scale Self-efficacy and their child's level of asthma control. The instrument was proved reliable and validated. The validity examination, based on the analysis of level of education and asthma clinical control parameters, found the expected association, corroborating the hypothesis of contrasted groups in the study.

The analysis developed in the present study indicated that the psychometric properties of transcultural adaptation of the Brazilian version of the scale are consistent and suitable for application in Brazil. These findings allow the authors to recommend the application of the instrument to evaluate the confidence of parents/guardians in childhood asthma control.

It is important that the translated and adapted version of the scale be applied in other research contexts and regions of Brazil. This way, it would be possible to continue and fully explore the psychometric properties validation process.

\section{REFERENCES}

1. Camacho-Rivera M, Kawachi I, Bennett GG, Subramanian SV. Associations of neighborhood concentrated poverty, neighborhood racial/ethnic composition, and indoor allergen exposures: a cross-sectional analysis of Los Angeles households, 2006-2008. J Urban Health [Internet]. 2014 [cited 2015 Jul 15];91(4):661-76. Available from: http://www.ncbi.nlm.nih.gov/pmc/articles/ PMC4134442/

2. Global Initiative For Asthma (GINA). World asthma day [Internet]. 2013 [cited 2013 Feb 17]. Available from: http://www. ginaasthma.com

3. World Health Organization (WHO). Global status report on noncommunicable diseases 2014: attaining the nine global noncommunicable diseases targets; a shared responsibility [Internet]. 2014 [cited 2015 Sep 30]. Available from: http://apps.who. int/iris/bitstream/10665/148114/1/9789241564854 eng.pdf?ua $=1$

4. American Thoracic Society (ATS). Asthma symptoms impair sleep quality and school performance in children [Internet]. 2014[cited 2015 Sep 25]. Available from: http://www.sciencedaily.com/releases/2013/05/130521105212.htm

5. Wood MR, Price JH, Dake JA, Telljohann SK, Khuder SA. African American parents 'guardians' health literacy and self-efficacy and their child's level of asthma control. J Pediatr Nurs[Internet]. 2010 [cited 2015 Sep 25];25(5):418-27. Available from: http://www. pediatricnursing.org/article/S0882-5963\%2814\%2900008-6/pdf

6. Zarei AR, Jahanpour F, Alhani F, Razazan N, Ostovar A. The impact of multimedia education on knowledge and self-efficacy among parents of children with asthma: a randomized clinical trial. J Caring Sci[Internet]. 2014[cited 2015 Sep 24];3(3):185-92. Available from: http://www.ncbi.nlm.nih.gov/pmc/articles/PMC4171813/

7. Joventino ES, Penha JC, Ximenes LB, Castro RCMB, Gomes ALA, Almeida PC. Effect of educational video about maternal selfefficacy and occurrence of childhood diarrhoea: randomized clinical trial. Indian J Appl Res[Internet]. 2015 [cited 2015 Oct 28];5(2):688-92. Available from: http://www.worldwidejournals.com/indian-journal-of-applied-research-\% 28IJAR\%29/file.php?v al =February_2015_1424258310_190.pdf

8. Dodt RCM, Ferreira AMV, Nascimento LA, Macêdo AC, Joventino ES, Ximenes LB. Influência de estratégia de educação em saúde mediada por álbum seriado sobre a autoeficácia materna para amamentar. Texto Contexto Enferm [Internet]. 2013 [cited 2016 May 16];22(3):610-8. Available from: http://www.scielo.br/pdf/tce/v22n3/v22n3a06.pdf

9. Bandura A. Self-efficacy: the exercise of control. New York: Freeman; 1997.

10. Beaton DE, Bombardier C, Guillemin F, Ferraz MB. Guidelines for the process of cross-cultural adaptation of self-report measures. Spine. 2000; 25(24): 3186-91.

11. Gomes ALA, Ximenes LB, Mendes ERR, Teixeira OCM, Joventino ES, Javorski M. Tradução e adaptação cultural da escala 
self-efficacy and their child's level of asthma control: versão brasileira. Texto Contexto Enferm [Internet]. 2016 [cited 2016 Dec 9];25(3):e2950015. Available from: http://www.scielo.br/pdf/tce/v25n3/pt_0104-0707-tce-25-03-2950015.pdf

12. Tabachnick BG, Fidell LS. Using multivariate statistics. New York: HarperCollins; 2001.

13. Martins G, Teophilo C. Metodologia da investigação científica para ciências sociais aplicadas. São Paulo: Atlas; 2009.

14. Landis JR, Koch GG. The measurement of observer agreement for categorical data. Biometrics. 1997;33(1):159-74.

15. Lakatos EM, Marconi MA. Fundamentos de metodologia científica. 7.ed. São Paulo: Atlas; 2010.

16. Mertler CA, Vannatta RA. Advanced and multivariate statistical methods: practical application and interpretation. Los Angeles: Pyrczak Publishing; 2005.

17. Joventino ES, Ximenes LB, Almeida PC, Oriá MO. The maternal self-efficacy scale for preventing early childhood diarrhea: validity and reliability. Public Health Nurs [Internet]. 2013 [cited 2015 Oct 14];30(2):150-58. Available from: http://www.ncbi.nlm.nih. gov/pubmed/23452109

18. Oriá, MOB, Ximenes LB. Tradução e adaptação cultural da Breastfeeding Self-Efficacy Scale para o português. Acta Paul Enferm [Internet]. 2010 [cited 2015 Oct 20];23(2):230-38. Available from: http://www.scielo.br/pdf/ape/v23n2/13.pdf

19. Fundo das Nações Unidas para a Infância (UNICEF). Índice de desenvolvimento infantil [Internet]. 2010 [cited 2015 Sep 30$].$ Available from: http://www.unicef.org/brazil/pt/activities_10181.htm

20. Jones B, Ingham TR, Reid S, Davies C, Levack W, Robson B. He Mãramatanga Huangõ: asthma health literacy for mãori children in New Zeland [Internet]. 2015 [cited 2015 Sep 30]. Available from: http://www.health.govt.nz/publication/ he-maramatanga-huango-asthma-health-literacy-maori-children-new-zealand

21. Valizadeh L, Zarei S, Zamanazadeh V, Bilan N, Nasiri K, Howard F. The Effects of Triggers' Modifying on adolescent self-efficacy with asthma: a randomized controlled clinical trial. J Caring Sci [Internet]. 2014[cited 2015 Sep 28];3(2):121-29. Available from: http://www.ncbi.nlm.nih.gov/pmc/articles/PMC4134172/

22. Harrington KF, Zhang B, Magruder T, Bailey WC, Gerald, LB. The impact of parent's health literacy on pediatric asthma outcomes. Pediatr Allergy Immunol Pulmonol [Internet]. 2015[cited 2015 Oct 10];28(1):20-6. Available from: http://www.ncbi.nlm.nih.gov/ pmc/articles/PMC4365507/

23. Stephan AMS, Costa JSD. Mothers of children with asthma's knowledge on the condition, in area covered by the family health program. Rev Bras Epidemiol [Internet]. 2009 [cited 2015 Sep 30];12(4):671-9. Available from: http://www.scielo.br/pdf/rbepid/ v12n4/16.pdf

24. Zhao J, Shen K, Xiang L, Zhang G, Xie M, Bai J, et al. The knowledge, attitudes and practices of parents of children with asthma in 29 cities of China: a multi-center study. BMC Pediatr [Internet]. 2013 [cited 2015 Jul 21];13(20):1-6. Available from: http://www. biomedcentral.com/content/pdf/1471-2431-13-20.pdf

25. Maspero JF, Jardim JR, Aranda A, Tassinari P, Gonzalez-Diaz SN, Sansores RH, et al. Insights, attitudes, and perceptions about asthma and its treatment: findings from a multinational survey of patients from Latin America. World Allergy Organ J [Internet]. 2013[cited 2015 Sep 30];6(1):19. Available from: http://waojournal.biomedcentral.com/articles/10.1186/1939-4551-6-19

26. Akinbami LJ, Moorman JE, Bailey C, Zahran HS, King M, Johnson CA, et al. Trends in asthma prevalence, health care use, and mortality in the United States 2001-2010. Nat Health Stat Rep [Internet]. 2012 [cited 2015 Oct 10];(94):1-8. Available from: http:// www.cdc.gov/nchs/data/databriefs/db94.pdf

27. Wang T, Srebotnjak T, Brownell J, Hsia RY. Emergency department charges for asthma-related outpatient visits by insurance status. J Health Care Poor Underserved [Internet]. 2014 [cited 2015 Sep 30];25(1):396-405. Available from: http://www.ncbi.nlm.nih. gov/pmc/articles/PMC4063557/

28. Andrews AL, Simpson AN, Basco JRWT, Teufel RJ. Asthma medication ratio predicts emergency department visits and hospitalizations in children with asthma. Medicare Medicaid Res Rev [Internet]. 2013[cited 2015 Sep 25];3(4):3-5. Available from: http://www.ncbi.nlm.nih.gov/pmc/articles/PMC4011648/

29. Stanford RH, Shah MB, D, Souza AO, Schatz M. Predicting asthma outcomes in commercially insured and medicaid populations. Am J Manag Care [Internet]. 2013 [cited 2015 Oct 10];19(1):60-7. Available from: http://www.ajmc.com/journals/ issue/2013/2013-1-vol19-n1/Predicting-Asthma-Outcomes-in-Commercially-Insured-and-Medicaid-Populations/

30. Gandhi PK, Kenzik KM, Thompson LA, Dewalt DA, Revicki DA, Shenkman EA, et al. Exploring factors influencing asthma control and asthma-specific health-related quality of life among children. Respir Res [Internet]. 2013[cited 2015 Sep 30];14(26):1-10. Available from: http://respiratory-research.biomedcentral.com/articles/10.1186/1465-9921-14-26 